\title{
PROBLEMS WITH SOLID WASTE COLLECTION IN KALININGRAD REGION AND DEVELOPMENT PERSPECTIVES
}

\author{
Leonid Primak ${ }^{l}$ \\ Sergey Kondratenko ${ }^{2}$ \\ ${ }^{\prime}$ Government of the Kaliningrad Region, Russia \\ ${ }^{2}$ Kaliningrad State Technical University, Russia
}

\begin{abstract}
Many reports and projects were devoted to the problem of waste collection and utilization in the Kaliningrad Region during the last 15 years. One article on this topic was published in the manuscript of EcoTech-1999 [1].

However, it must be accepted that this problem is so deep and complicated that now we have come to the next stage of solution. Presently, an effective system for household solid waste collection and utilization is absent in the region. There is no correct information about gravimetric values of waste delivered to landfills. Practically all 160 landfills do not meet Russian and international requirements, selective waste collection is not organized not more than $5 \%$ of all wastes are used as secondary raw materials.
\end{abstract}

\section{KEYWORDS}

Solid household waste management; Infrastructure; Social and legislative problems.

\section{INTRODUCTION}

Needed attention to the problem of waste collection and utilization was not paid during the Soviet time that is why the infrastructure needed (from residents' flats to polygons) was not created. Therefore, progressive experience of the other countries in waste management is necessary to adapt to nowadays reality with new socio-politic and economic conditions.

There have been previously several attempts of Eastern businessmen to start up own businesses with solid waste in Kaliningrad Region, but without any good result. There have been several international projects on studying the situation with waste in the region and developing recommendations for creation of an effective solid waste management. Such Tacis Project "Support to Waste Management in Kaliningrad Oblast" finished at the end of 2004. But since that time the situation with waste collection and utilization in the region has not changed. What are the main reasons?

\section{CONDITIONS TO DEVELOP WASTE MANAGEMENT}

There was not created stable and long term regional general management system and there is no continuity of the previous programs. Every new administration has its own view on solving various regional problems, including the problem on waste management. In general, such situation is connected to continuation of the legislative and administrative reforms. 
During the current historic period, the environmental legislation of Russia has been changed practically completely, and the basic law for environment protection was varied twice (in 1992 and 2002). Additionally, the whole state system for solid waste management was changed several times. Since 2004, the Federal Agency for Ecological, Technological and Nuclear Supervision (Rostechnadzor) is responsible for state control for observance of waste legislation in Russia. Since 2007, the largest part of such authorities was passed to the regional governments. Kaliningrad Region Government is ready to start up this activity but it waits for the final approval of the regional law "On the industrial and housing waste" to take place this autumn and new administrative-territorial system of the region. After that regional and municipal authorities will get more possibilities for solving waste problems taking into account specific situation in each settlement and district.

In this case, the financial possibilities of municipalities for the development of the solid waste management will become the matter of primary importance. But there are some perspectives here also - federal and regional programs for ecological rehabilitation and various international funds are ready to give financial resources to municipalities. To prepare in time basic information about situation with waste and own vision on this problem solving is needed from authorities. For example, Gusev Region has got financial support from EU program "Neighborhood" for designing the waste polygon. The Regional Government is ready to allocate funds from the regional budget for co-financing of this activity.

Furthermore, as an additional financial source for waste problem solving could be the payments of enterprises polluting environment. According to the Russian Budget Code ( $\mathrm{N}$ 145-FZ, 31.07.1998) $40 \%$ of payment for environment pollution must go in the regional budget (article 57) and other $40 \%$ - in the budgets of municipal districts and towns (article $62)$.

So far, the low level of tariffs for communal services for population is a serious obstacle for the attraction of private investments in solid waste management sphere. In many cases due to this reason the complicated and expensive to mountain objects for waste collection and utilization (modern polygons, waste burning plants and so on) were not built. But due to the restricted growth of tariffs there are enough modern financial mechanisms which make the processing of industrial and household wastes profitable. Housing Department of the Kaliningrad Region Government is ready to facilitate such activity.

Next group of problems is technical. Until now there is no single polygon and wastes sorting station meeting the nowadays requirements built in the region and there is no system of correct accounting of waste producing and land filling in weight units. All solid household wastes are calculated in the cubic meters and "by means of eye". Offering in official statistic materials weight amounts of waste are calculated by transferring coefficient of waste amount "by means of eye" into weight values. And just in 2007 a weighing machine is planned to be built in Kaliningrad City landfill. Then all places of waste sorting and landfilling could be equipped by the weighing machines.

Industrial waste values in the region are formed according to the data of the state statistic form named "N 2-TP (waste)" which was fulfilled in 2002 for example 153 enterprises, in 2003 - 216 [1] while economic actors (enterprises and companies) which due to Russian Legislation must give such report are about 40 thousand. During the last two years 
Rostechnadzor has been trying to put to rights in this field. Due to the last changes in the Russian waste management legislation the regional administrations have got the large power for state control on activity of economic actors dealing with waste producing excluding economic actors which are under federal state ecological control.

According to an expert estimations [2] the amount of waste generation in the Kaliningrad Region in 2003 were about 324,000 tons (see Table 1) but the collected waste were about 230,000 tons. Prognosis of waste generation in Kaliningrad region is shown in Table 1.

\section{Table 1. Projected estimation of solid waste generation in Kaliningrad}

\begin{tabular}{|l|c|c|c|c|c|c|}
\hline & 2003 & 2007 & 2010 & 2015 & 2020 & 2025 \\
\hline Household waste & 262 & 265 & 268 & 272 & 280 & 288 \\
\hline Not household waste & 62 & 63 & 63 & 64 & 66 & 68 \\
\hline Total & 324 & 328 & 331 & 336 & 346 & 357 \\
\hline
\end{tabular}

Note: Values is expressed in terms of thousand tons

As we can see at experts' prognosis the waste producing growth in the region will be about $10 \%$ during the next 20 years. In general in the country the household waste producing growth was more than $25 \%$ during the current historical period in Russia. That period was characterized of declining of paying capacity of population and falling down of society's interest to solving of environmental problems. Nowadays it has become a tradition very difficult to change. These are social and psychological problems. The first problem has been constantly solve for the last several years, but as the second one we have to make very wide and long term information campaign.

In the Kaliningrad Region there are no many places which have geographical and geological conditions meeting the requirements of the household waste polygons. But even the places, where conditions allow to built the polygon local society protests very active against such neighborhood.

During the Soviet period there was specific system for selective collection of waste (paper, glass, metal and so on) in the region. But during the period of the market reforms that system was destroyed, because several paper mils were closed and established state borders restricted delivery of waste to other regions of USSR for its processing. Now there is rather effective system for collecting of metals and glass for their further import to other countries. Also there are several small enterprises for collecting and processing of the car tires, plastic bottles and some other waste. But they collect and utilize very small part of the regional waste.

\section{PERSPECTIVES}

Now the regional authorities try to create effective waste management system taking into account all important internal and external aspects. One of them is the border with the EU countries. From the one side it is a good opportunity for creation of good cooperation for sending wastes in the EU for utilization. But from the other side so far the border is very difficult and not predictable bureaucratic obstacle for such business. In any case some political and economical contradictions between Russia and the EU could stop this activity. That is why there is a sense to create in the Kaliningrad Region autonomic system of waste management which could utilize the largest part of producing in the region waste. Nowadays, the world science generated a lot of technologies and techniques which give opportunities to 
choose the most appropriate for Kaliningrad Region's conditions variants for wastes processing taking into account including their amounts, payment capacity of population, ecological requirements and other conditions. The products produced could be heat and electric energy and raw materials which could be sent on the domestic and internal markets. Technologies and techniques could be chosen taking into account relatively small amounts of the produced wastes i.e. could be designed according to the mini technology principles which could be maximum set up to the source of waste producing. Such technologies could be both Russian and international. On being testing and reached max efficiency they could be disseminated further for other markets. There is such positive example in the region already one Kaliningrad Company has bought all rights on the pirolis installation, assembled it in Kaliningrad Region and creates the similar one in Lithuania.

Convenient place to create specialized technological park (technopark) for waste management in the Kaliningrad Region could be the waste landfill with surrounding territory near Kosmodemjansky village due to the following reasons:

- The largest part of waste in the region is produced in Kaliningrad City (minimal costs for transportation);

- Already accumulated large amount of waste which could be utilized in any case;

- Proximity to scientific and educational centers;

- Proximity to the new future city waste water treatment plant where could be created other environment protection object - wetland park.

Such innovation and technological center could be not only a place for waste utilization and designing of new technological equipment but a place for various scientific and educational events, exhibitions as well.

\section{CONCLUSIONS}

The following conclusions could be made:

- Problem for waste collecting and utilization in the Kaliningrad Region has not been solved so far;

- Good conditions for effective solving of this problem are created in the region:

- Park technologies for waste utilization could be as an element of future effective waste management system in the region.

\section{REFRENCES}

[1] Moutavtchi V. Solid waste management in the Kaliningrad Region: situation and perspective. Kalmar, Eco-Tech-99, 147-150.

[2] Доклад о состоянии и об охране окружающей среды Калининградской области в 2003 г./ Упр. Природ. Ресурсов и охраны окружающей среды МІТР России по Калинингр. обл. - Калининград: Янтарный сказ, 2004. - 216 с.

[3] Отчет Тасис проекта «Поддержка деятельности по обращению с отходами в Калининградской области» от 31.03.2004г. 